\title{
Rice Production, Technologies Adoption and Its Determining Factors in Fogera-Plain of North West Ethiopia
}

\author{
Misganaw Anteneh Tegegne Ayele Tesfahun Adane Melak \\ Fogera National Rice Research and Training Center -Ethiopian Institute of Agricultural Research \\ P.O.Box, 1937, Woreta, Ethiopia
}

\begin{abstract}
The study was conducted in Fogera plain which is one of rice production hubs in South Gondar Zone in North West part of Ethiopia on rice production, adoption of technologies and its determinant factors for small holder rice producing farmers. A total sample size of respondents $(n=74)$ were selected through random sampling method. Binary logistic regression model was applied to the specification of socio-economic, demographic and institutional factors determining to adoption of improved rice technologies. Both continuous and categorical variables were used based on their logical and statistical hypothesis in relation to adoption of rice technologies. Poor infrastructure, timely un-availability of technology, membership of the household to farm organizations such as cooperatives, access to farm credit and price of technologies were statistically and significantly identified as determinant factors for adoption of improved rice technologies. Age, family size, sex, education level, farming experience, access to extension and advisory services of the household head and size of cultivated land didn't significantly affect adoption of technologies. Hence it is recommended that availability of improved technologies at appropriate time, infrastructural development to rice producing farmers and strengthening farmers' organizations especially seed cooperatives as well as efficient access of farmers to credit and saving services in their proximate areas were paramount importance to enhance adoption of improved rice technologies.

Keywords: Adoption, Fogera plain, improved variety, Oryza Sativa
\end{abstract}

DOI: $10.7176 / \mathrm{JESD} / 12-7-06$

Publication date: April $30^{\text {th }} 2021$

\section{Introduction}

Rice (Oryza sativa L.) which belongs to the family Poaceae is a semi-aquatic plant, although there are few upland varieties. Rice probably originated in South-East Asia, but today it is widely grown in other parts of Asia; America and Africa. In the early 1970s Ethiopia was hit by a severe famine which took the lives of hundreds thousands of human beings (estimations range from 250,000 to 750,000 people) and countless domestic animals (Kebede et al., 1988). Owning to observation of the potential of the area for rice cultivation via identification of wild rice grown in the area, introduction and cultivation of rice for the first time in Ethiopia specifically in Fogera and Gambella plain has been taken as a response to the dramatic phenomena by the government in collaboration with north Korean development cooperation (Belayineh etal, 2017). From then on rice cultivation, mostly undertaken by small-scale farmers, has expanded to several plains and wetlands nationwide (Alemu et al. 2011).

Since then the Government of Ethiopia (GoE) has given higher consideration for rice production with an increasing rate from year to year. For instance, the current five-year plan, GTP II Rice seen as a priority crop to ensure food security through increasing the average productivity from $27.8 \mathrm{qt} / \mathrm{ha}$ in 2015 to $41 \mathrm{qt} / \mathrm{ha}$ in 2020 and increased the total volume of produce from 1.3 million quintals in 2015 to 2.03 million quintal by the year 2020 ( GTP II, 2015). Due to the interventions of collaboration work of GOs and other partners, over the recent past the number of rice producer farmers, area under rice, rice production volume and yield of rice increased dramatically. According to CSA (2015), 118,079 small holder farmers engaged in rice production. In 2006 area under rice was 6,241 ha with yield of 1.8 tons/ha and total production of 11,244 tons of rice. In 2015 then area, yield and production of rice jumped to 46,832 ha, 2.8 tons/ha and 13,1821 tons respectively witnessing more than 75 -fold increase in area, a tone increase in productivity ( $56 \%$ increase) and 11.7 -fold increase in production only within a decade.

In the country, the demand for rice consumption is increasing as rice is used for different purposes and food types (Temesgen et al 2014). It is compatible with various traditional food recipes like Injera (traditional Ethiopian bread), and local beverages (like "tela" and "areki"). While Ethiopia's annual rice production increased, it still does not satisfy the growing internal market demand (Takele, et al .2017). To meet the increasing demand for rice in the local market, introduction and development of high yielding varieties, multiplication and dissemination of quality improved seed, use of agricultural inputs including post-harvest machineries, capacity building and follow up to realize farmers use of recommendations from the production packages as well as enhancing value chain approach based rice production, cluster farming, motivate private investors to start commercialized irrigated rice farming are mentioned as the major interventions areas in national Growth and Transformation Plan II (GTP II) of the country (GTP II, 2015). 
It is still believed that there are a number of rice technologies (varieties and their agronomic practices) with a lot of merits that are adopted by the farmers. Availability of the different rice technologies by themselves will not be sufficient requirements for a better adoption of the technologies by smallholder farmers. Farm households' socioeconomic, demographic characteristics and their access to different institutions are the most important variables which influence farmers' decision on their farming activities. Therefore the main objective of this study is to figure out determinant factors for adoption of improved rice technologies in Fogera plain which is known as huge hubs of rice production in the country.

\subsection{Objectives}

$>$ To assess socio-economic and demographic characteristics of smallholder rice producing households

$>$ To assess major crops production, land allocation and marketing patterns

$>$ To identify determinant factors affecting adoption of improved rice technologies

\section{Methodology}

\subsection{Description of the Study Areas}

The study was conducted at two districts (known as Fogera and libokemkem) of South Gondar province in Amhara region in North West part of the country. South Gondar province is known by huge potential in rice production which approximately covers $70 \%$ of rice grain supply in the country. It has 12 districts and a total population of 2,051,738, of which 1,041,061 are men and 1,010,677 women and with an area of 14,095.19 square kilometers. The average rural household had 1 hectare of land compared to the national average of 1.01 hectare of land and an average of 0.75 for the Amhara Region. The altitude ranges between 1820-2040 meters above sea level. The mean annual rainfall is $1284 \mathrm{~mm}$ and monthly average temperature ranges $18-28^{\circ} \mathrm{c}$.

\subsection{Sampling Method}

The two districts were selected purposively as both of them have relatively higher potential and capacity in terms of rice production and coverage. List of rice producing households have been assessed from records and documentations in study districts. After having the lists of the households, sampling was undertaken from the population using the simple random sampling technique.

\subsection{Data Collection}

Semi structure questionnaire based interview, key informant interview and Focused Group Discussion (FGD) were used to collect cross sectional data. The questionnaire was designed with Cspro-software version 7.2 and pre-tested before the actual data collection. Both quantitative and qualitative types of data were collected from primary and secondary sources. Primary data were collected from rice producing households and secondary data were collected from records and documentations of different organizations such as Central Statistical Agency (CSA), FAOSTATT official data records, zonal and district level agricultural offices.

\subsection{Methods of Data Analysis}

To do analysis, both Statistical Package for Social Science (SPSS) and R-software were used. Descriptive statistics like mean, percentage and standard deviation were applied to characterize and describe rice producing households. Inferential statistical tools which are independent $t$ test and chi square test were employed to compare means of continuous explanatory variables and indicate the relationship/interdependency of dummy explanatory variables of adoption category, respectively. This study used binary logistic regression model to identify the determinants of probability of improved rice technologies adoption.

$\operatorname{logit}(p)=\ln (p) /(1-p)=\beta 0+\beta 1 x 1 \ldots \beta i x i$

Where $x i=x_{1}, x_{2} x_{3} \ldots i=1,2 \ldots$ are explanatory variables, $\beta_{1}, \beta_{2}, \beta i \ldots i=1,2 \ldots$ are the coefficients of explanatory variables and $\beta_{0}$ is the intercept.

Log odds of the variety adoption for $\mathrm{x} 1=1,+\beta 1(1)+\beta i x i=\beta 0+\beta 1+\beta i x i$ and $\mathrm{x} 1=0, \mathrm{~B} 0+\beta 1(0)+$ $\beta i x i=\mathrm{B} 0+\beta i x i$ then by exponentiation it, odds of variety choice for $\mathrm{x} 1=0$ and $\mathrm{x} 1=1$ would be $e^{\mathrm{B} 0}+B i x i$ and $e^{\mathrm{B} 0}+$ $\beta 1+\beta i x i$, respectively. Thus, the odds ratio or marginal effect (going from $\mathrm{x} 1=0$ to $\mathrm{x} 1=1$ ) is:

Odd ratio/marginal effect $=\frac{\text { Odds when } x=1}{\text { Odds when } x=0}, \frac{\mathrm{e}^{\mathrm{B} 0}+\beta_{1}+\beta_{2}}{\mathrm{e}^{\mathrm{B} 0}+\beta_{2}+\mathrm{X}_{2}}=\mathrm{e}^{\beta 1}$

And $\mathrm{p}^{\wedge}=\frac{\mathrm{e}^{\mathrm{B} 0}+\beta 1 x 1}{1+\mathrm{e}^{\mathrm{B} 0}+\beta 1 x 1}$ probability of adoption for estimated regression equation

Logistic regression predicts probabilities, and therefore it can be fitted using likelihood. The binary output variable $\mathrm{Y}$ is to be expressed as the conditional probability $\operatorname{Pr}(\mathrm{Y}=1 \mid \mathrm{X}=\mathrm{x})$ as a function of $\mathrm{x}$; the vector of features, $x i$, and an observed class, yi. The probability of that class is either $p$, if $y i=1$, or $1-p$, if $y i=0$. The likelihood is then, 
Any unknown parameters in the function are to be estimated by maximum likelihood through using derivative function. Moreover logarithm of odd ratio is $\beta 1$ (Bewick et al. 2005) and (Richard Kay et al.2018).

$\log (p)$

$(1-p)=\beta_{0}+\beta_{1} S E X H H+\beta_{2} A G E H H+\beta_{3} F A M S I Z+\beta_{4} L A N D S I Z+\beta_{5} F A R M E X+\beta_{6} M C O O P+$ $\beta_{7}$ TTECH $+\beta_{8}$ PTECH $+\beta_{9}$ POORINFRA $+\beta_{10}$ FARMCRED $+\beta_{11}$ EDUHH $+\beta_{12}$ EXTEN

\section{Results and Discussion}

\subsection{Socio-economic and Demographic Characteristics}

From the total sampled rice producing households in this study, $(8.1 \%)$ of them were female headed households. Regarding to literacy status of the household heads, $(51.4 \%)$ of them were not able to read and write, on the contrary $(48.6 \%)$ of household heads were able to read and write at least through informal schools such as religious, adult education (meserete timihirit*). About marital status of the household heads, $(91.9 \%)$ of respondents were married, (6.9\%) were widowed and (1.4\%) was divorced. (83.8\%) of respondents engaged in rice production either in rain fed lowland or upland production system and $(16.2 \%)$ of them were involved in production of other crops such as tef, maize, grass pea, chickpea. Heads of the households were interviewed in which economic status is categorized based on their own asset and wealth parameters in the community, $(10.8 \%)$ of the households were rich, (71.6\%) were medium and (17.6\%) of them were poor.

\subsection{Agricultural Extension and Advisory Services}

In this study, (90.5\%) of them adopted improved livestock production technologies (It might include improved fodder, cross bred, X-bred through AI, including improved poultry production) and (64.9\%) of the households received extension and advisory services on livestock production and managements. (75.7\%) of the households received extension and advisory services on crop production and management practices mainly through personal contact, farmers' field day, demonstration and farm to farm visits. And (77\%) of households received extension advisory services on natural resource managements. (27.4\%) of the household heads accessed opportunity of experience sharing through farm to farm visits. The extent of satisfaction on extension services provided was evaluated relying on qualitative parameters and the reaction given by the heads of the households.

Absence of improved technology was an issue for $(77 \%)$ of the household heads in their crop production. Furthermore, in-accessibility of improved technologies was also a challenge for (71.6\%) of households. Lack of supply of technologies in a sufficient amount and timely un-availability of fertilizer were issues for $(81.1 \%)$ and $(87.8 \%)$ of the households, respectively. Apart from this, price of fertilizer was also expensive for more than $(90 \%)$ of households. (85.1\%) of the household heads had shortage of farm lands. Poor infrastructure was an issue for (44.6\%) of household heads. Lack of credit facilities was an issue for (49.6 \%) of the households.

\subsection{Crop Production}

From sampled households, $16.4 \%$ used improved variety for first major crop production and $26 \%$ of the households adopted improved variety for second major crop and 16.4\% of households adopted improved variety in the third major crop production. Sources of seed in the first, second and third major crops were from farmers own re-volving seed production. (24.7\%) of the households used row planting method for first major crop production and $56.2 \%$ of the households also used row planting method for second major crop production and $30.1 \%$ of the households applied row planting method for third major crop production. The first major crops for the households were rice, finger millet and maize. Rice is the first major crop production for $90.4 \%$ of the respondent households, finger millet and maize also the first major crop productions for $8.2 \%$ and $1.4 \%$ of the households, respectively. In the second major crop categories maize took the largest proportion accounting for $49.3 \%$ of the households and grass pea was the second largest with $16.4 \%$ of the households. Finger millet and chickpea had the same proportion which accounts for $11 \%$ of the households. $(12.3 \%)$ of them under second major crops were rice, onion and among others. The third major crops produced by the households were finger millet, maize, and grass pea having the same proportions with (20.5\%) households engaged per each crop. $(24.7 \%)$ of the households didn't have third major crops. (13.8\%) of the households produced other crops as third major crops such as rice, onion, pepper, tef and sorgum. The average production of first major crop was ( 2.535 metric tons) and ( 0.664 metric tons) for the second crop and ( 0.56 metric ton) for third crop

\subsection{Land holdings and Allocation Patterns}

The average cultivated area of upland rice production was $(0.41)$ hectares in Fogera district and $(0.49)$ hectares in Libokemkem district. On the other hand the mean cultivated area of lowland rice production was $(0.66)$ hectares in Fogera district and (0.54) hectares in Libokemkem district. The average value of rain-fed-cultivated land was $(0.74)$ hectares in Fogera district and $(0.85)$ hectares in Libokemkem district. The average irrigated cultivated land was $(0.31)$ hectares in Fogera and $(0.04)$ hectares in Libokemkem districts. The average land 
allocated for grazing was (0.06) hectares in Fogera and (0.03) hectares in Libokemkem districts. The mean rented in land was (0.06) hectares in Fogera and (0.13) hectares in Libokemkem districts, while (0.01) hectares rented out land in both Fogera and Libokemkem districts. The average shared in land was $(0.12)$ hectares in Fogera and (0.18) hectares in Libokemkem districts. The mean shared out land was $(0.02)$ hectares and $(0.04)$ hectares in Fogera and Libokemkem districts, respectively. The average harvested area of first major crop was (0.6) hectares, $(0.4)$ hectares for second crop and (0.37) hectares for third crop.

\subsection{Income and marketing of agricultural products}

The average income earned from sale of production of first major crops in the last year production was 348.89 United States Dollars (USD) per household. Furthermore, 82.09 USD and 38.81 USD were earned on average from production of second and third major crops, respectively. The maximum incomes earned by the households were 2344 USD, 797.3 USD and 442.9 USD from production of first, second and third major crops, respectively. The total volume marketed from first crop production was 1.214 metric tons, and 0.334 metric ton for second crop and 0.132 metric ton for third major crop production. The average consumption per household from first crop production was 1.26 metric tons and 0.33 metric ton from second crop production and 0.325 metric ton of consumption from third crop production.

Table1 Descriptive statistics of socioeconomic characteristics

\begin{tabular}{|c|c|c|c|c|c|c|c|}
\hline Description of variables & Range & Min & Max & Sum & Mean & S.E & S.D \\
\hline Harvested area of $1^{\text {st }}$ major crop (ha) & 2 & 0.0 & 2 & 47 & 0.64 & 0.04 & 0.34 \\
\hline Harvested area of $2^{\text {nd }}$ major crop (ha) & 2 & 0.0 & 2 & 28 & 0.38 & 0.06 & 0.52 \\
\hline Harvested area of $3^{\text {rd }}$ major crop (ha) & 2 & 0.0 & 2 & 27 & 0.37 & 0.06 & 0.52 \\
\hline Production of $1^{\text {st }}$ major crop ( $\left.\mathrm{Mt} *\right)$ & 9 & 0.0 & 9 & 185.05 & 2.535 & 0.11 & 1.71 \\
\hline Production of $2^{\text {nd }}$ major crop (Mt) & 2.5 & 0.0 & 2.5 & 48.45 & 0.664 & 0.063 & 0.54 \\
\hline Production of $3^{\text {rd }}$ major crop (Mt) & 10 & 0.0 & 10 & 40.8 & 0.56 & 0.155 & 1.32 \\
\hline Volume consumed in $1^{\text {st }}$ major crop (Mt) & 5 & 0.0 & 5 & 92 & 1.26 & 0.119 & 1.02 \\
\hline Volume consumed in $2^{\text {nd }}$ major crop (Mt) & 1.3 & 0.0 & 1.3 & 24.1 & 0.33 & 0.032 & 0.27 \\
\hline Volume consumed in $3^{\text {rd }}$ major crop (Mt) & 5 & 0.0 & 5 & 23.7 & 0.325 & 0.075 & 0.64 \\
\hline Volume marketed in 1 st major crop (Mt) & 5 & 0.0 & 5 & 88.6 & 1.214 & 0.116 & 0.991 \\
\hline Volume marketed in $2^{\text {nd }}$ major crop $(\mathrm{Mt})$ & 1.8 & 0.0 & 1.8 & 24.4 & 0.334 & 0.048 & 0.411 \\
\hline Volume marketed in $3^{\text {rd }}$ major crop (Mt) & 1.0 & 0.0 & 1.0 & 9.5 & 0.132 & 0.028 & 0.241 \\
\hline Income earned from sale of $1^{\text {st }}$ crop (USD*) & 2344 & 0.0 & 2344 & 25469 & 348.89 & 44.28 & 378.28 \\
\hline Income earned from sale of $2^{\text {nd }}$ crop (USD) & 797.3 & 0.0 & 797.29 & 5992.57 & 82.09 & 16.12 & 137.76 \\
\hline Income earned from sale of $3^{\text {rd }}$ crop (USD) & 442.9 & 0.0 & 442.93 & 2833.5 & 38.81 & 8.89 & 75.35 \\
\hline Mt* = metric tons, & $\begin{array}{l}\text { USD }^{*}= \\
\text { Decem }\end{array}$ & nitec & tes & r IIS & & & Birr, \\
\hline
\end{tabular}

Source: Survey result, 2020

\subsection{T-test on socioeconomic characteristics of households}

T-test statistical analysis was conducted for continuous explanatory variables to describe whether there are statistical mean differences between adopters and non-adopters. As the result shown in the table 3, age of the households' head was not significantly different between adopters and non-adopters and family size of the household had no statistically significant variation between adopters and non-adopters. Cultivated land size of the households was not significantly different between adopters and non-adopters of improved rice technology. There was no statically significant mean difference of farming experience in years between adopters and nonadopters of rural farming households.

Table2. T-test analysis for equality of means on socio-economic characteristics of households between adopters and non-adopters

\begin{tabular}{lllllll}
\hline Description of variables & \multicolumn{2}{c}{ Adopter } & \multicolumn{2}{c}{ Non-adopter } & \multicolumn{2}{c}{ T-test } \\
\cline { 2 - 7 } & Mean & S.D & Mean & S.D & T & p-value \\
\hline Age of the household & 40.13 & 8.774 & 42.83 & 12.779 & -0.581 & 0.563 \\
Family size & 5.88 & 2.031 & 5.38 & 2.292 & 0.584 & 0.561 \\
Cultivated land (ha) & 0.859 & 0.440 & 0.763 & 0.512 & 0.511 & 0.611 \\
Farming experiences (years) & 21.38 & 9.753 & 22.94 & 13.152 & -0.325 & 0.746 \\
\hline \multicolumn{1}{c}{$\mathrm{N}=74$} & $* * *, * *$, and $*$ statistically significant at $1 \%, 5 \%$ and $10 \%$ \\
\hline
\end{tabular}

\subsection{Hypothetical and Logical Description of Determinant Variables}

Selected explanatory variables were hypothetically and logically specified to the model on adoption of improved rice technologies. These variables include socio-economic, demographic and institutional characteristics 
Table3. Variables specified on the model and their hypothesized signs

\begin{tabular}{|c|c|c|c|}
\hline Variable & $\begin{array}{l}\text { Label and } \\
\text { description }\end{array}$ & $\begin{array}{l}\text { Hypothesized } \\
\text { sign }\end{array}$ & Logic \\
\hline SEXHH & $\begin{array}{l}\text { Sex of the } \\
\text { household head } \\
{[1=\text { male, } 0=} \\
\text { female ] }\end{array}$ & + & $\begin{array}{l}\text { Male headed households might have better access to } \\
\text { technology than female headed } \mathrm{HH} \text {, adoption depends } \\
\text { on access to land, labor, or other resources, and if in a } \\
\text { particular context men tend to have better access to } \\
\text { these resources than women }\end{array}$ \\
\hline AgeHH & $\begin{array}{l}\text { Age of household } \\
\text { (years) }\end{array}$ & \pm & $\begin{array}{l}\text { Old farmers are less receptive to new ideas and are less } \\
\text { willing to take risks. On the other hand adoption } \\
\text { increased if it is supported by experience and education, } \\
\text { older farmers are assumed to have gained knowledge } \\
\text { and experience over time and are better able to evaluate } \\
\text { technology information than younger farmers }\end{array}$ \\
\hline FamSIZ & Family size (no) & + & $\begin{array}{l}\text { family size determines its scale of production as rice is } \\
\text { labor intensive where mechanizing farming is lower in } \\
\text { developing countries }\end{array}$ \\
\hline LandSIZ & $\begin{array}{l}\text { Cultivated land } \\
\text { size (ha) }\end{array}$ & + & $\begin{array}{l}\text { The larger cultivated land size the higher probability to } \\
\text { adopt the technology }\end{array}$ \\
\hline FarmEx & $\begin{array}{l}\text { Farming } \\
\text { experience (years) }\end{array}$ & + & $\begin{array}{l}\text { The more farming experience the higher probability to } \\
\text { adopt technology }\end{array}$ \\
\hline MCOOP & $\begin{array}{l}\text { Membership to } \\
\text { cooperative } \\
{[1=\text { yes, } 0=\text { no }]}\end{array}$ & + & $\begin{array}{l}\text { Member to seed cooperatives can have the probability to } \\
\text { get improved seed }\end{array}$ \\
\hline TTECH & $\begin{array}{l}\text { Timely } \\
\text { availability of } \\
\text { technology } \\
{[1=\text { yes, } 0=\text { no }]}\end{array}$ & + & $\begin{array}{l}\text { Supply of technology at appropriate time for farmers } \\
\text { can increase adoption }\end{array}$ \\
\hline PTECH & $\begin{array}{l}\text { Price of the } \\
\text { technology } \\
{[1=\text { yes, } 0=\text { no }]}\end{array}$ & - & $\begin{array}{l}\text { The higher price of technology less likely to afford and } \\
\text { adopt it }\end{array}$ \\
\hline POORINFRA & $\begin{array}{l}\text { Poor infrastructure } \\
{[1=\text { yes, } 0=\text { no }]}\end{array}$ & - & $\begin{array}{l}\text { Poor infrastructure contribute to less accessibility of } \\
\text { technology }\end{array}$ \\
\hline FARMCRED & $\begin{array}{l}\text { Access to farm } \\
\text { credit } \\
{[1=\text { yes, } 0=\text { no }]}\end{array}$ & + & $\begin{array}{l}\text { If access to credit the financial capability of households } \\
\text { cane be enhanced to buy technology }\end{array}$ \\
\hline EDUHH & $\begin{array}{l}\text { Education level of } \\
\text { the household } \\
\text { head } \\
{[1=\text { able to read }} \\
\text { \&write, } 0=\text { not } \\
\text { able to read \& } \\
\text { write }]\end{array}$ & + & $\begin{array}{l}\text { Literacy can change attitude and improve knowledge } \\
\text { and thought for better understanding of the benefits of } \\
\text { technology }\end{array}$ \\
\hline EXTEN & $\begin{array}{l}\text { Extension and } \\
\text { advisory services } \\
{[1=\text { yes, } 0=\text { no }]}\end{array}$ & + & $\begin{array}{l}\text { Farmers are usually informed about the existence as } \\
\text { well as the effective use and benefit of new technology } \\
\text { through extension agents }\end{array}$ \\
\hline
\end{tabular}

\subsection{Association of explanatory variables with dependent variable}

Analysis of chi-square test was applied to characterize statistical association of predictor parameters with dependent variable; in this case adoption of improved rice technology. Those specified independent variables were categorical or discrete variables labeled with binary values. The result of chi-square test shows that sex of the household head and adoption decision are interdependence to each other. There is interdependence or relationship between adoption decision and cooperative membership and statistically significant at $1 \%$ level of significance. This implies that adopters are members of the cooperative. The result of chi-square test shows that there is an interdependence or relationship between untimely availability of the technology for the households and adoption decision and is statistically significant at $1 \%$ level of significance. This implies that adopters are getting the technologies timely than the non-adopters. There is interdependency between poor infrastructure and adoption decision and the relationship is statistically significant at $1 \%$ level of significance. This implies that adopters have access to infrastructure than the non-adopters. Price of technology was not statistically 
independent from adoption of improved rice technology. It was significantly interrelated at less than $1 \%$ level of significance. Household's access to credit and adoption decision are interrelated to each other and is statistically significant at $1 \%$ level of significance. This implies that farmers having access to credit are adopters.

Table 4 The relationship of categorical variables with dependent variable using chi-square test

\begin{tabular}{|c|c|c|c|c|c|}
\hline \multirow[t]{2}{*}{ Categorical variables } & \multicolumn{3}{|c|}{ Percentage } & \multirow[b]{2}{*}{$\mathbf{x}^{2}$} & \multirow[b]{2}{*}{ p-value } \\
\hline & Adopter & Non-adopter & Total & & \\
\hline \multicolumn{6}{|l|}{ Sex of the household head } \\
\hline Male & 9.46 & 82.43 & 91.89 & 0.232 & 0.630 \\
\hline Female & 1.31 & 6.76 & 8.07 & & \\
\hline \multicolumn{6}{|l|}{ Membership of cooperative } \\
\hline Yes & 2.70 & 50.00 & 52.7 & 78.836 & 0.000 \\
\hline No & 8.11 & 39.19 & 47.3 & & \\
\hline \multicolumn{6}{|l|}{ Timely un-availability of technology } \\
\hline Yes & 9.45 & 62.16 & 71.61 & 77.143 & 0.000 \\
\hline No & 1.35 & 27.03 & 28.38 & & \\
\hline \multicolumn{6}{|l|}{ Price of the technology } \\
\hline Yes & 8.11 & 75.7 & 83.81 & 76.523 & 0.000 \\
\hline No & 2.7 & 13.5 & 16.2 & & \\
\hline \multicolumn{6}{|l|}{ Poor infrastructure } \\
\hline Yes & 2.7 & 41.89 & 44.59 & 77.432 & 0.000 \\
\hline No & 8.11 & 47.23 & 55.34 & & \\
\hline \multicolumn{6}{|l|}{ Access to farm credit } \\
\hline Yes & 4.05 & 44.59 & 48.64 & 76.458 & 0.000 \\
\hline No & 6.75 & 44.59 & 51.34 & & \\
\hline \multicolumn{6}{|c|}{ Education level of the household head } \\
\hline Able to read \& write & 2.71 & 45.94 & 48.65 & 2.01 & 0.156 \\
\hline Not able to read \& write & 8.10 & 43.24 & 51.34 & & \\
\hline \multicolumn{6}{|l|}{ Extension and advisory services } \\
\hline Yes & 9.46 & 66.21 & 75.67 & 0.681 & 0.409 \\
\hline No & 1.35 & 22.97 & 24.32 & & \\
\hline
\end{tabular}

\subsection{Determinants of adoption of improved rice technologies}

Hypothesis was already designed in the above table 3 on both categorical and continuous independent variables with respect to adoption of improved rice technology. Adopter in this case does mean a farming household head that was able to adopt improved rice variety and on the other hand the household head who didn't adopt was considered as non-adopter because of different influencing factors. Therefore, the dependent variable is the adoption decision. In this study, improved rice variety was defined varieties released by research institutions and selected or ranked in comparison with local or farmers' varieties using several parameters and traits such as comparative yield advantage, biomass, early maturity, cold and disease resistant via multidisciplinary approach along with farmers and different stakeholders.

Specified and hypothesized determinant factors were taken into account in the logistic regression model to test their effects statistically on adoption of improved rice technology.

Age of the household head negatively influences adoption though it was not statistically significant. It shows old farmers are less receptive to new ideas and are less willing to take risks than young farmers. This result is consistent with Afewerk et al., (2015), Oluwarotimi O. F. et al., (2006), Onumadu, F. N., et al, (2014), Shamsudeen et al., (2018), Takele, A., (2017), Tiamiyu, S.A et al.,(2009) and Yemane Asmelash, (2014), but opposite result was obtained with the finding of Chandio et al.,(2018). Household family size and education affect positively the decision of farmers on adoption nevertheless it was not statistically significant. The result in this study also consistent with the finding of Afewerk et al., (2015), Chandio et al.,(2018), Oluwarotimi O. F. et al., (2006), Shamsudeen et al., (2018), Takele, A., (2017), Tiamiyu, S.A et al.,(2009) and Yemane Asmelash, (2014).

Land size and farming experience of the household influence positively farmers' decision on adoption of the technology but not statistically significant. The result is in line with Afewerk et al., (2015), Chandio et al.,(2018), Oluwarotimi O. F. et al., (2006), Onumadu, F. N., et al, (2014), Shamsudeen et al., (2018), Takele, A., (2017), Tiamiyu, S.A et al.,(2009) and Yemane Asmelash, (2014). Sex of the household head had positive effect on decision of adopting the technology. This is consistent with result of Takele, A., (2017), Shamsudeen et al., (2018) and Yemane Asmelash, (2014). Extension and advisory services had positive influence on adoption of the technology even though it was not statistically significant. This is consistent with results of Afewerk et al., (2015), Chandio et al.,(2018), Tiamiyu, S.A et al.,(2009) and Yemane Asmelash, (2014). Farmers are usually got 
access of information about the existence as well as the effective use and benefit of new technology through extension agents

Membership of the farming household to agricultural cooperatives or organizations had more likely to adopt improved rice technology than non-member households. As the result revealed in table 5, the factor influences adoption positively and statistically significant at $5 \%$ level of significance $(\boldsymbol{\beta}=\mathbf{2 . 2 7 5}, \mathbf{p}=\mathbf{0 . 0 5 0})$. Membership of the households in agricultural organizations increases adoption of improved rice technology by 2.275 times than non-members. The logic behind was when the households being member of cooperatives they could have the probability to get improved seed and credit loans if they are for instance involved in rice seed multiplication and marketing cooperative. It is also common that if farmers were organized they might have been prioritized and benefited from improved crop production technologies and practices than individuals. This result is consistent with hypothesized sign in the logical description prior. The result is also in line with the finding of Onumadu, F. N., et al, (2014), Ray Lamtin, (1999), Samuel et al., (2017), Shamsudeen et al., (2018), Tiamiyu, S.A et al.,(2009) and Yemane Asmelash, (2014) but it was contrary with result of Oluwarotimi O. F. et al., (2006)

Poor infrastructure like main road and accessibility of the areas could influence adoption of improved rice technology negatively and statistically significant at $10 \%$ level of significance $(\boldsymbol{\beta}=\mathbf{- 0 . 6 0 2}, \mathbf{p}=\mathbf{0 . 0 8 6})$. This shows adoption of improved rice technology could increase by $6.02 \%$ more with in the situation availability of good infrastructure in rural farming households. The result is consistent with hypothesized sign above. Many studies such as Chandio et al.,(2018), Tiamiyu, S.A et al.,(2009) and Yemane Asmelash, (2014) were consistent with the result in this study. Experience of farmers in rice production positively influenced adoption and it is consistent with the result of Onumadu, F. N.,et $a l$, (2014) and Tiamiyu, S.A et al.,(2009)

In several studies, accessibility of farm credit facilities and services were identified as one of the determinant factors in adoption of technologies. In this study as the result shows access to credit services positively and significantly influence adoption at $10 \%$ level of statistical significance $(\boldsymbol{\beta}=\mathbf{2 . 0 6 3}, \mathbf{p}=\mathbf{0 . 0 9 1})$. This does indicate that adoption could increase by 2.063 more times if the households get access to credit services. This is consistent with the hypothesized sign. The logical description was when the households could have access to credit; they would have higher financial capability and availability of agricultural inputs and farm implements. The result is consistent with Chandio et al., (2018) and Tiamiyu, S.A et al.,(2009)

Price of the technology influence adoption negatively at $5 \%$ of level of statistical significance $(\boldsymbol{\beta}=-\mathbf{5 . 3 0 0}$, $\mathbf{p}=\mathbf{0 . 0 2 8}$ ). The logical explanation was affordability of the technologies to be supplied for famers was paramount importance, the higher the price of the technology, farmers could not afford it as if their financial capability is relatively poor. Adoption of improved rice technology was less likely decreased by $(-5.300)$ by the households if price of the technology is expensive. The result is consistent with hypothesized sign.

Timely un-availability of technology indirectly associated with institutional factor had negative effect and less likely to adopt improved rice technology than those households getting the technology on time. This can be further explained in the way that when technology supply for farmers was too late, there would be a tendency that farmers had to use their own local variety instead. The result shows this independent variable statistically and negatively influence adoption at $5 \%$ level of significance $(\boldsymbol{\beta}=\mathbf{- 5 . 4 8 7}, \mathbf{P}=\mathbf{0 . 0 3 5})$. Besides, adoption of technology could be decreased less likely by 5.487 when farmers didn't get or received the technology at the right time. This is consistent with hypothesized sign. The result was consistent with Mustapha, S.B., et al (2012)

Different statistical evidences could be presented to confirm whether the model fits with data or not. The predictors could explain the dependent variable up to $49.8 \%$ (pseudo $\mathbf{R}^{\mathbf{2}}=\mathbf{0 . 4 9 8}$ ). The insignificant value of Hosmer-Lemeshow test reveals that the model is good fit with the data $\chi^{\mathbf{2}}(\mathbf{8}, \mathbf{N}=\mathbf{7 4}) \mathbf{= 3 . 9 2 3 ,} \mathbf{p}=\mathbf{0 . 8 6 4}$. The omnibus tests of model coefficients shows that the model was statistically significant at $5 \%$ level of significance $\chi^{\mathbf{2}}(\mathbf{1 2}, \mathbf{N}=\mathbf{7 4})=\mathbf{2 0 . 9 7 7}, \mathbf{p}=\mathbf{0 . 0 5}$. Adding additional socio-economic variables in the model has produced a reduction of value of $\mathbf{- 2 l o g}$ likelihood $=\mathbf{2 9 . 7 1 9}$ from the initial value of $\mathbf{- 2 l o g}$ likelihood statistic $=\mathbf{5 3 . 1 1 6}$. The above tests for evidences give us guarantee that the model was fitting to the data. 
Table5. Factors determining adoption of rice technologies

\begin{tabular}{|c|c|c|c|c|}
\hline Independent Variables & Coefficient & S.E & p-value & $\operatorname{Exp}(\beta)$ \\
\hline Age of household head (years) & -0.011 & 0.131 & 0.932 & 0.989 \\
\hline Household family size(no) & 0.409 & 0.370 & 0.269 & 1.505 \\
\hline Membership to agricultural cooperative & 2.275 & 1.171 & $0.050 * *$ & 9.727 \\
\hline Poor infrastructure & -0.602 & 1.317 & $0.086^{*}$ & 1.496 \\
\hline Sex of household head & 2.409 & 2.266 & 0.288 & 5.190 \\
\hline Education status of the household head & 1.303 & 1.512 & 0.389 & 4.272 \\
\hline Extension and advisory services & 2.180 & 1.658 & 0.189 & 8.846 \\
\hline Farm credit services & 2.063 & 1.220 & $0.091 *$ & 7.872 \\
\hline $\begin{array}{l}\text { Farming experiences of household head } \\
\text { (years) }\end{array}$ & 0.049 & 0.120 & 0.680 & 0.952 \\
\hline Price of technology & -5.300 & 2.412 & $0.028 * *$ & 0.436 \\
\hline Time supply of technology & -5.487 & 2.598 & $0.035 * *$ & 0.004 \\
\hline Cultivated land (ha) & 0.688 & 1.228 & 0.575 & 1.990 \\
\hline $\begin{array}{r}\text { Pseudo } \mathbf{R}^{2}=\mathbf{0 . 4 9 8}, \quad-2 \log \text { likelihood }=29.719, \\
* * * * *, \text { and } * \text { statistically significant at } 1 \%, 5 \%\end{array}$ & $\begin{array}{l}\text { HL Ch } \\
\text { and } 10 \%\end{array}$ & 3.923, & 864 & \\
\hline
\end{tabular}

\section{Summary, Conclusion and policy recommendations}

The study assessed on rice production, technology adoption and determinant factors affecting adoption of rice technology in Fogera plain of North West part of the country, Ethiopia. In this study and some other studies conducted so far confirmed that various factors determining adoption of improved rice technologies among small holder farmers even though there are a number of rice technologies (improved varieties and agronomic practices) released, packaged and recommended by research institutions with a lot of merits. Binary logistic regression model was used to specify socio-economic, demographic and institutional factors affecting adoption of the technology. Some of the factors identified and significantly influence adoption on improved rice technology were: poor infrastructure, price of the technology, lack of access to farm credit and saving services, lack of involvement of rice producing farmers in cooperatives of seed multiplication and inappropriate time availability of the technology. Hence, availability of improved technologies at appropriate time, infrastructural development to rice producing farmers and strengthening social capital especially seed cooperatives as well as efficient access of farmers to credit and saving services in their proximate areas were paramount importance to enhance adoption of improved rice technologies.

\section{References}

Afewerk,H., Lemma,Z., 2015. Determinants of improved rice varities adoption in Fogera district of Ethiopia. Science, Technology and Arts Research Journal Sci. Technol. Arts Res. J., Jan-March 201 Journal, DOI: http://dx.doi.org/10.4314/star.v4i1.35 ISSN: 2226-7522(Print) and 2305

Alemu, D., Shiratori, K., 2011. Stakeholder Analysis in Rice Research and Development. Challenges and Opportunities of Rice in Ethiopian Agricultural Development, FRG II Project, Ethiopian Institute of Agricultural Research, 24-31.

Belayineh, T., Jember, T., 2017. Review On Adoption, Trend, Potential, and Constraints of Rice Production to Livelihood in Ethiopia. International Journal of Research -Granthalaayah 5(6), 2394-3629.

Bewick, V., Cheek,L., Jonathan, B., 2005. Statistics review 14: Logistic regression. School of Computing, Mathematical and Information Sciences, University of Brighton, Brighton, UK, 9:112-118, DOI 10.1186/cc3045.

Chandio, A., Jiang, Y., 2018. Determinants of Adoption of improved Rice Varieties in Northern Sindh, Pakistan. In Rice Science 25 (2), pp. 103-110. DOI: 10.1016/j.rsci.2017.10.003. College of Economics, Sichuan Agricultural University, Chengdu 611130, China.

Kebede, G., Jacob, M. J., 1988. Drought, Famine and the Political Economy of Environmental Degradation in Ethiopia. Geography, 73(1), 65-70.

National Growth and Transformation Plan II (GTP II) of the country, 2015

Mustapha, S.B., Undiandeye, U.C., Sanusi, A.M., Bakari, S., 2012. Analysis of adoption of improved rice production technologies in Jeer local government area of Borno state, Nigeria. International Journal of Development and Sustainability Online ISSN: 2168-8662- www.isdsnet.com/ijds 1( 3), Article ID: IJDS12091101

Oluwarotimi, O. F., Oladimeji, L. O., Martins, O. A., Dele, T.,Toshiyuki, W., 2006. Socio-economic factors influencing the adoption of sawah rice production technology

in Nigeria. Journal of Food, Agriculture 
and Environment, 5 ,239-242.2007, www.world-food.net

Onumadu, F. N., Osahon, E. E., 2014. Socio-economic determinants of adoption of improved rice technology by farmers in Ayamelum local government area of Anambra State, Nigeria. International Journal of Scientific and Technology Research, 3(1), 308-314.

Ray, L., 1999. Rice Post-harvest Operations, International Rice Research Institute

Richard Kay et al. (2018): Transformations of the Explanatory Variables in the Logistic Regression Model for Binary Data.

Shamsudeen, A., Abraham, Z., Samuel, D., 2018. Adoption of rice cultivation technologies and its effect on technical efficiency in Sagnarigu district of Ghana. Journal of Cogent, Food and Agriculture.DOI:http://doi.org/10.1080/23311932.2018.142429

Takele, A., 2017.Determinants of Rice Production and Marketing in low Producer Farmers: the Case of Fogera Districts, North-Western Ethiopia. International Journal of Environment, Agriculture and Biotechnology, 2(5).2456-1878, http://dx.doi.org/10.22161/ijeab/2.5.34

Temesgen, Y., Tilahun, D., Belay, B., 2014. Production Expansion, Competitiveness and Comparative Advantage of Upland Rice Production: Case of Fogera and Libokemekem Plain in Ethiopia. The International Journal of Applied Economics and Finance, 8(2), 48-50.

Tiamiyu, S.A., Akintola, J.O., Rahji, M.A., 2009. Technology Adoption and Productivity Difference among Growers of New Rice for Africa in Savanna Zone of Nigeria. Tropicultura, 27, 4, 193-197

Yemane, A., 2014. Determinants of adoption of upland rice varieties in Fogera district, South Gondar, Ethiopia. Journal of Agricultural Extension and Rural Development, 8(12), 332-338, DOI: 10.5897/JAERD12.10 